\title{
31. MAGNETIC LINEATIONS IN THE SHIKOKU BASIN ${ }^{1}$
}

\author{
Tai-chang Shih, Geophysics Laboratory, Marine Science Institute, The University of Texas at Austin
}

\section{INTRODUCTION}

Correlation of magnetic anomalies to determine the age of oceanic crust (Vine and Matthews, 1963; Morley and Larochelle, 1964; Heirtzler et al., 1968) has greatly advanced our understanding of the evolution of oceanic areas. Recently, this approach has been applied to a number of marginal basins, where magnetic lineations have been mapped and convincingly correlated with the geomagnetic-reversal time scale (e.g., Cooper et al., 1976, Bering Basin; Watts et al., 1977, South Fiji Basin). In other areas, magnetic lineations have been recognized, but correlations with the reversal time scale have been difficult (e.g., Isezaki and Uyeda, 1973, Sea of Japan; Ben-Avraham and Uyeda, 1973, South China Sea). These difficulties may be due to complex geology, insufficient data, or unfavorable orientation and location of the lineations.

Previously unpublished magnetic-anomaly data from the Shikoku Basin, combined with published data, have allowed study of the details of magnetic lineations in this marginal basin. On the basis of these details, I propose new interpretations of the age and pattern of magnetic lineations of the area.

\section{MAGNETIC ANOMALIES AND LINEATIONS}

This study utilizes unpublished data from the Marine Geophysical Surveys (MGS) program of the U.S. Naval Oceanographic Office (NAVOCEANO). Published magnetic-anomaly data from Lamont-Doherty Geological Observatory, the Ocean Research Institute (University of Tokyo), Scripps Institution of Oceanography, and NAVOCEANO were also used (e.g., Watts and Weissel, 1975; Kobayashi and Nakata, 1977).

The MGS magnetic anomalies were derived by removing the International Geomagnetic Reference Field (IGRF) (IAGA, 1969) from the total-field measurements. These data were plotted together with most of the available data as anomalies along ship tracks (Figure 1 in pocket of volume).

The addition of the MGS data to published data of Tomoda et al. (1975) and Watts and Weissel (1975) has significantly improved the quality of magnetic correlation in the Shikoku Basin. With these additional data, I have been able to interpret the lineation pattern throughout the basin, except in its axial area. Some recently released magnetic data (Kobayashi and Nakata, 1977) allow examination of the details of lineations in the south-

${ }^{1}$ University of Texas Marine Science Institute contribution No. 331, Geophysics Laboratory. central part of the Shikoku Basin. Difficulties in map projections leave uncertainties about how to add the Japanese data to Figure 1.

The amplitude of magnetic anomalies in the Shikoku Basin is greater than in the neighboring West Philippine Basin and the Parece Vela Basin. Their wavelengths along east-west tracks in the Shikoku Basin are far shorter than along north-south tracks, suggesting that the lineation direction is almost north-south. Anomalies of similar shapes can be correlated along the direction $\mathrm{N} 20^{\circ} \mathrm{W}$ (Figures 1 and 2). Anomalies in the western part of the Shikoku Basin can be traced for more than $500 \mathrm{~km}$ without major disruptions. In the eastern part of the basin, however, anomalies can be traced only for about $100 \mathrm{~km}$, and a disrupted lineation pattern is observed.

The wavelength of the anomalies in the Shikoku Basin is short, averaging $30 \mathrm{~km}$. This suggests slow opening of the basin, or possible association with the lateTertiary rapid-reversal sequence.

\section{PREVIOUS STUDIES}

In the context of plate tectonics, marginal basins are areas of crustal extension behind island arcs (Karig, $1970,1971)$. Such extension has been attributed to processes induced by subduction, such as magmatic diapirism caused by frictional heating (Turcotte and Oxburgh, 1969; Hasebe et al., 1970) or subsidiary convections in the asthenosphere above the subducting plate (Holmes, 1965; Toksöz and Bird, 1977). The extension may be a two-limbed, symmetrical process of spreading (Karig, 1970, 1971; Moberly, 1972) or a one-limbed process (Packham and Falvey, 1971). Study of magnetic lineations and results from Deep Sea Drilling Project sampling may resolve this problem of the formation of marginal basins.

Prior to DSDP Leg 58 drilling, a number of different correlation schemes on the magnetic lineations from the Shikoku Basin were proposed by Tomoda et al. (1975), Watts and Weissel (1975), Murauchi and Asanuma (1978) and Kobayashi and Nakata (1978). These agree with the DSDP results only in part (Table 1).

Watts and Weissel (1975) mapped a set of almost north-south-trending anomalies in the western part of the Shikoku Basin as anomalies 7 ( $\sim 25.5$ m.y.) through $5 \mathrm{E}(\sim 18 \mathrm{~m} . \mathrm{y}$.$) , and tentatively identified some frag-$ mentary lineations in the eastern part of the basin as anomalies $5 \mathrm{E}$ to $5 \mathrm{~A}(\sim 11 \mathrm{~m} . \mathrm{y}$.). This is a single-limbed model. Alternatively, they proposed that the eastern lineations may be the counterpart of the anomalies in the western part of the Shikoku Basin in a two-limbed spreading model. Kobayashi and Nakata (1978: also 


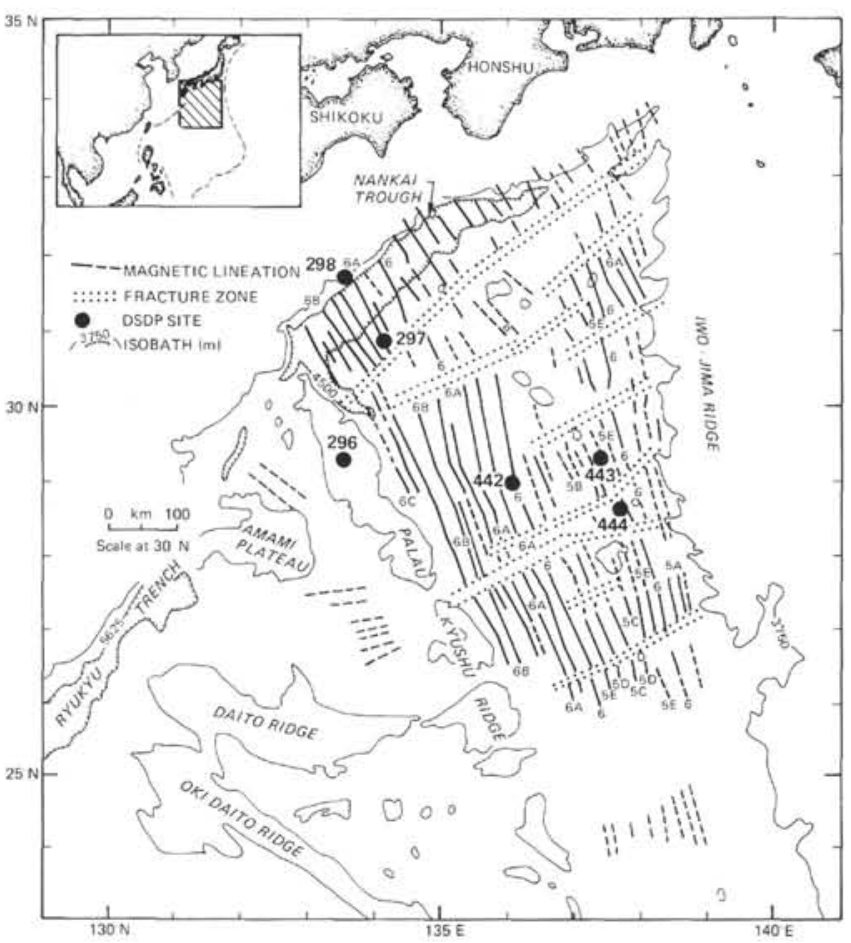

Figure 1. Magnetic-anomaly pattern of the Shikoku Basin, deduced from this study. Correlations of magnetic anomalies are indicated by solid or dashed (tentative) lines. Dotted lines indicate fracture zones. The bathymetric contours, in uncorrected meters, are from Chase and Menard (1969).

favored a two-limbed spreading model from anomalies 7 through 5D ( $\sim 17$ m.y.).

DSDP Leg 58 recovered basement rocks of Miocene age from both the western and eastern parts of the Shikoku Basin (Klein, Kobayashi et al., 1978; Scientific Staff, 1978). The inferred age of basement at Site 442 (in the western part of the basin) is 18 to $21 \mathrm{~m} . y$. , in excellent agreement with an anomaly-6 age ( $\sim 19$ m.y.) predicted for this site by Watts and Weissel (1975) and Kobayashi and Nakata (1978). On the other hand, the age of the basal sediment inferred from drilling at Sites 443 and 444 is about 15 m.y., whereas the symmetricalspreading models of Watts and Weissel (1975) and Kobayashi and Nakata (1978) place anomaly 6A ( 21 m.y.) at this site. The asymmetrical-spreading model of Watts and Weissel (1975) appears to agree best with DSDP drilling results in the eastern part of Shikoku Basin, but the 14-m.y. (after anomaly 5A) age predicted from this model is less than that of the basal sediments. This does not support their model as a likely solution for the lineations for this part of the Shikoku Basin.

\section{CORRELATION OF MAGNETIC ANOMALIES IN THE SHIKOKU BASIN}

The magnetic anomalies from the Shikoku Basin are identified by comparing anomaly profiles, projected normal to the lineation direction, with model profiles generated from the reversal sequence of LaBrecque et al. (1977) (Figure 3); tracks of these profiles are shown

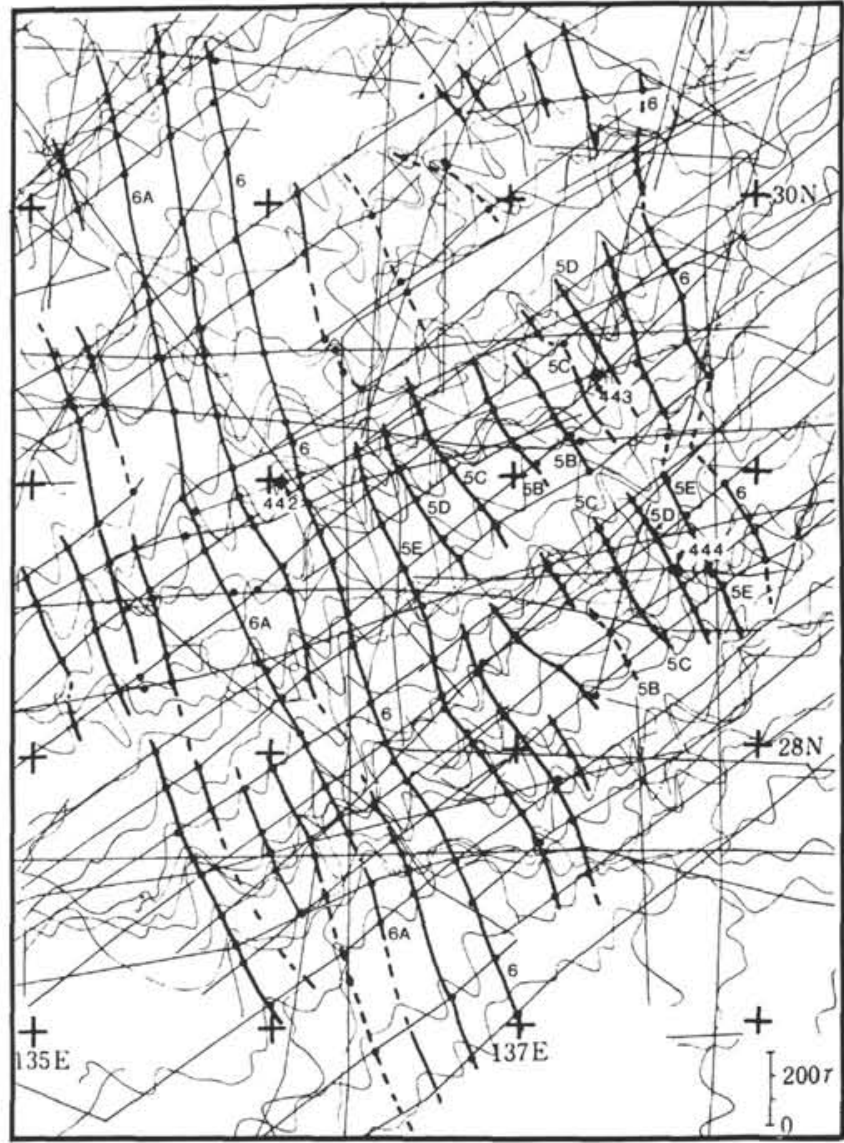

Figure 2. Interpretation of the magnetic-lineation pattern in the southern sector of the Shikoku Basin. The anomaly data are from Kobayashi and Nakata (1977). Correlations are shown by solid lines or dashed (tentative) lines.

TABLE 1

Predicted Ages of the DSDP Sites from Magnetic Anomalies and Leg 58 Drilling Results, Shikoku Basin

\begin{tabular}{|c|c|c|c|}
\hline \multirow[b]{2}{*}{ Sources } & \multicolumn{3}{|c|}{ Predicted Ages } \\
\hline & $\begin{array}{l}\text { DSDP } \\
\text { Site } 442\end{array}$ & $\begin{array}{l}\text { DSDP } \\
\text { Site } 443\end{array}$ & $\begin{array}{l}\text { DSDP } \\
\text { Site } 444\end{array}$ \\
\hline $\begin{array}{l}\text { Tomoda et al., } 1975 . \\
\text { Symmetrical spreading: } \\
\text { anomaly } 5 E(18 \text { m.y.), } \\
\text { anomaly } 5 \mathrm{~A}(12 \mathrm{~m} . \mathrm{y} .)\end{array}$ & $\begin{array}{l}\text { Younger than } \\
\text { anomaly } 5 \mathrm{~B} \text { : } \\
13 \mathrm{~m} . \mathrm{y} \text {. }\end{array}$ & $\begin{array}{l}\text { Younger than } \\
\text { anomaly } 5 \mathrm{~B} \text { : } \\
13 \mathrm{~m} . \mathrm{y} \text {. }\end{array}$ & $\begin{array}{l}\text { Younger than } \\
\text { anomaly } 5 \mathrm{~B} \text { : } \\
13 \mathrm{~m} . \mathrm{y} \text {. }\end{array}$ \\
\hline $\begin{array}{l}\text { Watts and Weissel, } 1975 \text {. } \\
\text { Asymmetrical spreading: } \\
\text { anomaly } 7 \text { ( } 25.5 \text { m.y.), } \\
\text { anomaly } 5 \text { A (11 m.y.). }\end{array}$ & $\begin{array}{l}\text { Anomaly 6: } \\
19.5 \mathrm{~m}, \mathrm{y} \text {. }\end{array}$ & $\begin{array}{l}\text { Younger than } \\
\text { anomaly } 5 \mathrm{~B} \text { : } \\
14 \mathrm{~m} . \mathrm{y} \text {. }\end{array}$ & $\begin{array}{l}\text { Younger than } \\
\text { anomaly } 5 \mathrm{~B} \text { : } \\
14 \text { m.y. }\end{array}$ \\
\hline $\begin{array}{l}\text { Symmetrical spreading: } \\
\text { anomaly } 7 \text {, anomaly } 5 \mathrm{E} \text {. }\end{array}$ & $\begin{array}{l}\text { Anomaly 6: } \\
19.5 \mathrm{~m} . \mathrm{y} \text {. }\end{array}$ & $\begin{array}{l}\text { Younger than } \\
\text { anomaly } 6 \mathrm{~B}: \\
21.5 \text { m.y. }\end{array}$ & $\begin{array}{l}\text { Younger than } \\
\text { anomaly } 6 \mathrm{~B} \text { : } \\
21.5 \mathrm{~m} . \mathrm{y} \text {. }\end{array}$ \\
\hline $\begin{array}{l}\text { Murauchi and Asanuma, } 1978 \text {. } \\
\text { Two-stage opening: } 24-20 \\
\text { m.y. and } 12-6 \text { m.y. }\end{array}$ & $\begin{array}{l}\text { Anomaly } 4 \text { : } \\
7 \mathrm{~m} . y \text {. }\end{array}$ & $\begin{array}{l}\text { Anomaly } 5 \mathrm{E} \text { : } \\
18.5 \mathrm{~m} . \mathrm{y} \text {. }\end{array}$ & $\begin{array}{l}\text { Anomaly } 5 \mathrm{E} \text { : } \\
18.5 \mathrm{~m} . \mathrm{y} \text {. }\end{array}$ \\
\hline $\begin{array}{l}\text { Kobayashi and Nakata, } 1978 \text {. } \\
\text { Symmetrical spreading: } \\
\text { anomaly } 7 \text {, anomaly 5D } \\
\text { (17 m.y.) }\end{array}$ & $\begin{array}{l}\text { Anomaly 6: } \\
19.5 \text { m.y. }\end{array}$ & $\begin{array}{l}\text { Anomaly 6A: } \\
21 \mathrm{~m} . \mathrm{y} \text {. }\end{array}$ & $\begin{array}{l}\text { Anomaly } 6 \mathrm{~A} \text { : } \\
21 \mathrm{~m} . \mathrm{y} \text {. }\end{array}$ \\
\hline $\begin{array}{l}\text { Shih, this study. } \\
\text { Symmetrical spreading: } \\
\text { anomaly 6C ( } 24 \text { m.y.), } \\
\text { anomaly 5B (14.5 m.y.). }\end{array}$ & $\begin{array}{l}\text { Anomaly 6: } \\
19.5 \text { m.y. }\end{array}$ & $\begin{array}{l}\text { Between anomaly } \\
\text { SD and anomaly } \\
5 C: 17-16 \text { m.y. }\end{array}$ & $\begin{array}{l}\text { Anomaly 5D: } \\
17 \text { m.y. }\end{array}$ \\
\hline $\begin{array}{l}\text { DSDP Leg } 58 \text { inferred base- } \\
\text { ment age, Klein, Kobayashi, } \\
\text { et al., } 1978 .\end{array}$ & $\begin{array}{l}\text { Early Miocene } \\
18-21 \text { m.y. }\end{array}$ & $\begin{array}{l}\text { Middle Miocene } \\
\sim 15 \text { m.y. }\end{array}$ & $\begin{array}{l}\text { Middle Miocene } \\
\sim 15 \text { m.y. }{ }^{\text {a }}\end{array}$ \\
\hline
\end{tabular}

${ }^{\mathrm{a}}$ Ages of basal sediments. 


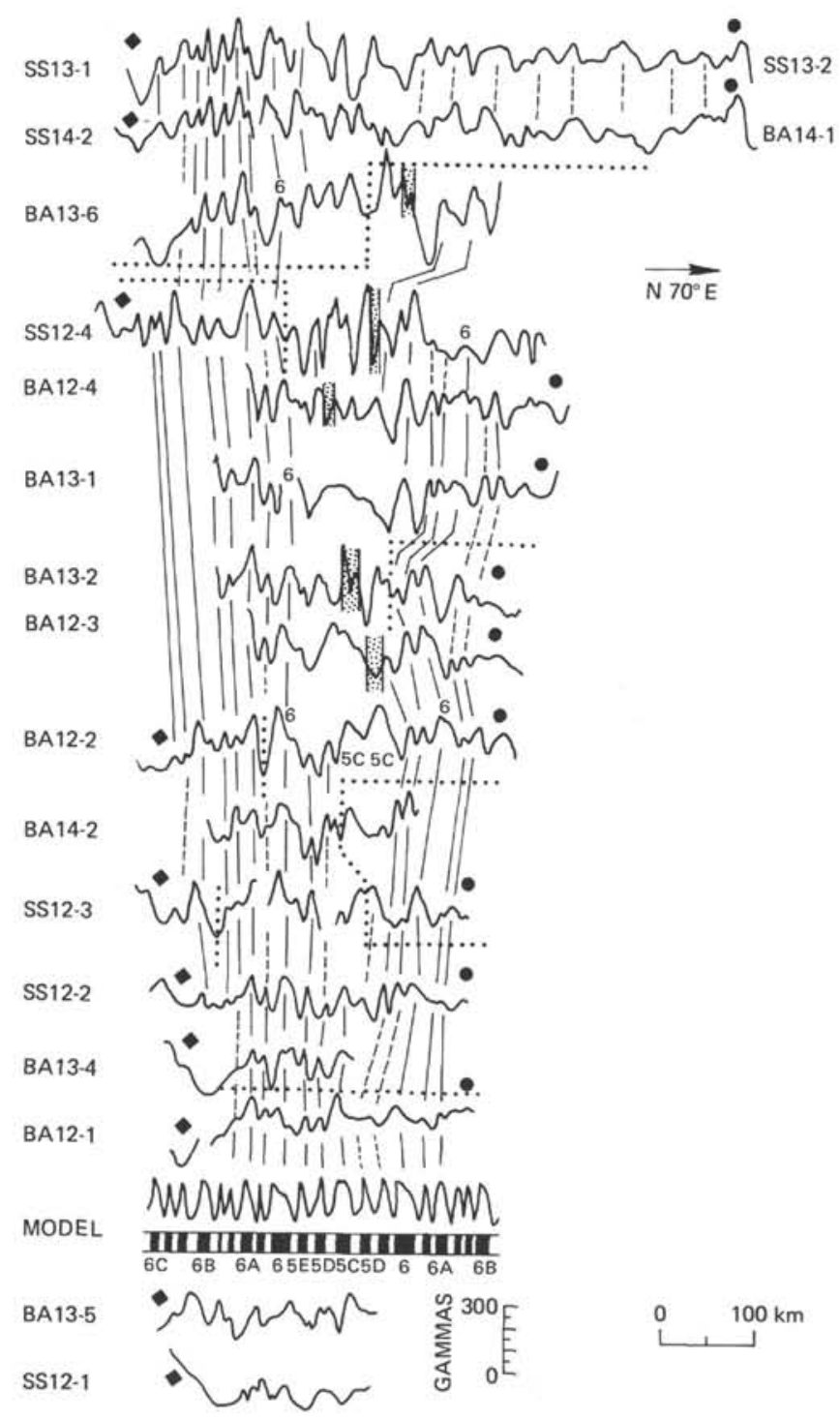

Figure 3. Representative MGS magnetic-anomaly profiles from the Shikoku Basin. All profiles have been projected normal to the inferred lineation direction in this basin. Tracks of these profiles are shown in Figure 4. The dotted lines indicate the positions of postulated fracture zones. The shaded areas denote anomalies associated with seamounts. The filled circles indicate the edge of the Iwo Jima Ridge, and the filled diamonds the Palau-Kyushu Ridge. The model assumes a magnetic layer $0.5 \mathrm{~km}$ thick, at a water depth varying between 4.0 and $4.6 \mathrm{~km}$, with a strength of remanent magnetization of $0.006 \mathrm{emu/}$ $\mathrm{cm}^{3}$, and a spreading direction of $N 70^{\circ} \mathrm{E}$. Spreading rates for the model are indicated in Figure 7.

in Figure 4. Short anomaly sequences characteristic of anomalies 6A ( $\sim 21$ m.y.) to 5D ( $\sim 17$ m.y.), found in both the western and eastern parts of the Shikoku Basin (Figure 5), suggest that this basin opened up by twolimbed spreading. The anomalies in both halves of the basin are skewed towards the same side (to the west). This is expected if they were formed from the same ridge

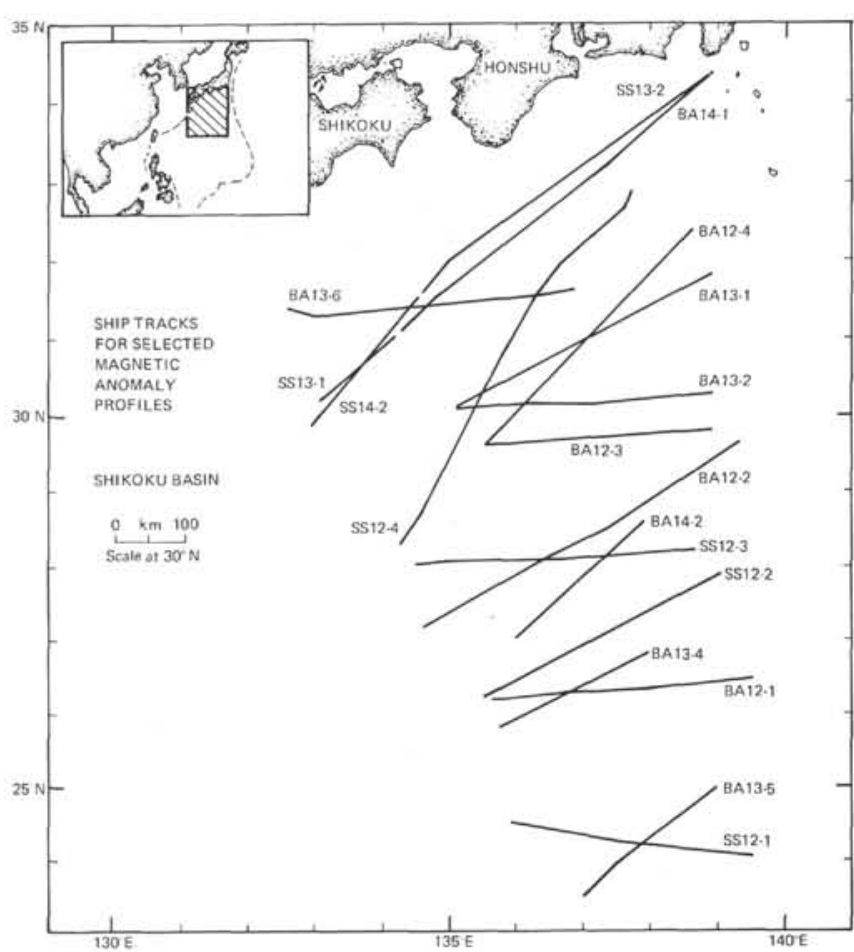

Figure 4. Track chart of magnetic-anomaly profiles shown in Figures 3 and 6.

and have undergone only a small amount of rotation, thus having the same skewness.

The normal event of anomaly 6 ( $\sim 19.5$ m.y.) is the wide peak in the sequence from anomalies $6 \mathrm{~A}$ to $5 \mathrm{D}$, with a two-peak sequence on either side. The peak of the older event of the 6A doublet normally is the more prominent of the two. Magnetic lineations interpreted by shape and sequence as anomalies $6 \mathrm{~A}$ and $5 \mathrm{D}$ can be traced in most of the western half of Shikoku Basin for over $500 \mathrm{~km}$ (Figures 1 and 3). Although their correlative sequences can be identified in parts of the eastern half of the basin, detailed examination shows that these sequences can be traced uninterruptedly for about 100 $\mathrm{km}$. The anomaly configuration thus produced has long, continuous magnetic lineations in the western half of the basin, and lineation disrupted by a number of postulated fracture zones in the eastern half (Figure 1). These proposed fracture zones align very well with topographic discontinuities in the Iwo Jima Ridge (east of the Shikoku Basin) shown by Karig and Moore (1975).

In general, the correlation of magnetic lineations presented in this study supports the previous correlation by Watts and Weissel (1975) in the western half of Shikoku Basin. In the MGS data for the very northernmost part of the basin, anomaly "6B" of Watts and Weissel (1975) looks more like anomalies 6A to 6 (BA 13-1, SS 13-1, and SS 14-2; Figure 1). However, my correlation would require two major fracture zones in the northern sector of the basin. Therefore, better data coverage is needed to verify this interpretation in the area. 

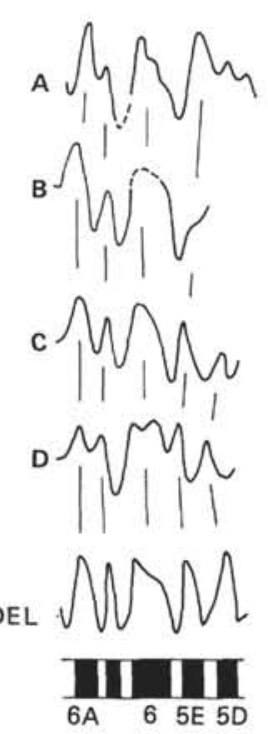
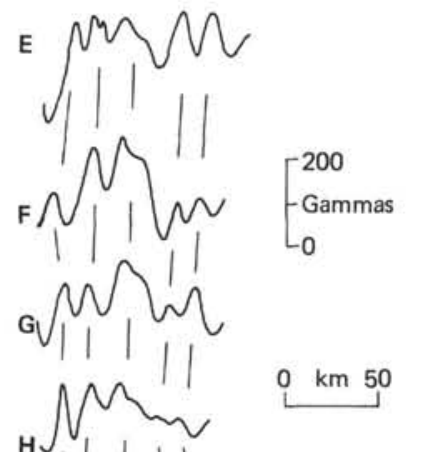

$\mathrm{N} 70^{\circ} \mathrm{E} \longrightarrow$

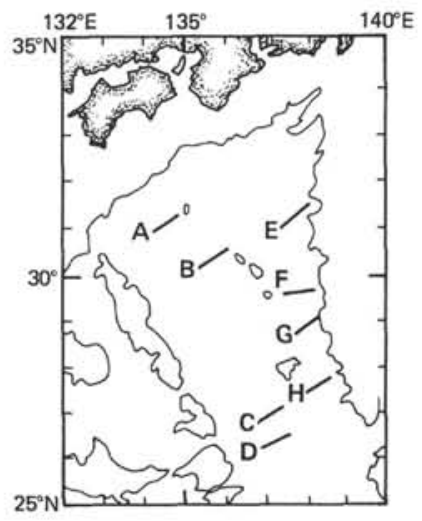

Figure 5. Selected anomaly profiles (projected normal to the lineation direction in the Shikoku Basin) suggesting that mirror images of anomalies $6 A$ through $5 D$ exist in both the western and eastern parts of the Shikoku Basin.

On extending my correlation of MGS data toward the axial part of the southern Shikoku Basin, I identify anomaly $5 \mathrm{C}(\sim 16 \mathrm{~m} . \mathrm{y}$.$) as the central anomaly (BA$ 12-2, SS 12-2; Figure 6). The very dense tracks of Kobayashi and Nakata (1977) permit me to see details of lineation patterns in the central and southern sectors of the Shikoku Basin. Using their data, I identify anomaly 5B ( $\sim 14.5$ m.y.) as the central anomaly of a two-limbed spreading sequence about $100 \mathrm{~km}$ north of profile BA $12-2$ (close to $29^{\circ} \mathrm{N} 137^{\circ} \mathrm{E}$; Figure 2). The Kobayashi and Nakata data also show that the lineation trend from anomalies $5 \mathrm{C}$ to $5 \mathrm{~B}$ is about $\mathrm{N} 30^{\circ} \mathrm{W}$, which is slightly different from the $\mathrm{N} 20^{\circ} \mathrm{W}$ trend of the anomalies older than $5 \mathrm{D}$ in this basin. This possibly implies a shift in the pole of spreading at a time between anomalies $5 \mathrm{E}(\sim 18$ m.y.) and 5D ( $\sim 17$ m.y.).

The spreading rates derived from my correlation of magnetic anomalies in the Shikoku Basin (Fig. 7) indicate a gradual slowing of spreading toward cessation of opening. In the western part of the basin, the half spreading rate between anomalies $7(?)(\sim 25.5 \mathrm{~m} . \mathrm{y}$.) and 6B ( $\sim 22.5 \mathrm{~m} . \mathrm{y}$.) is about 4.8 to $5.3 \mathrm{~cm} / \mathrm{yr}$, between anomalies $6 \mathrm{~B}$ and 6 ( $\sim 19.5 \mathrm{~m} . \mathrm{y}$.) about $2.4 \mathrm{~cm} / \mathrm{yr}$, and between anomalies 6 and 5B ( $\sim 14.5$ m.y.) about 1.7 $\mathrm{cm} / \mathrm{yr}$. The half spreading rates seem to be slower in the eastern part of the basin, about $2.2 \mathrm{~cm} / \mathrm{yr}$ between anomalies $6 \mathrm{~A}$ and 6 , and about $1.5 \mathrm{~cm} / \mathrm{yr}$ between anomalies 6 and $5 \mathrm{~B}$.

The Shikoku Basin is wider in the northern end than in the southern end. This northward "fanning" of the basin may be explained partly by a slightly higher half spreading rate $(5.3 \mathrm{~cm} / \mathrm{yr})$ between 29 and $31^{\circ} \mathrm{N}$ than that $(4.8 \mathrm{~cm} / \mathrm{yr})$ farther south. This small difference in spreading rates, however, is not sufficient to account

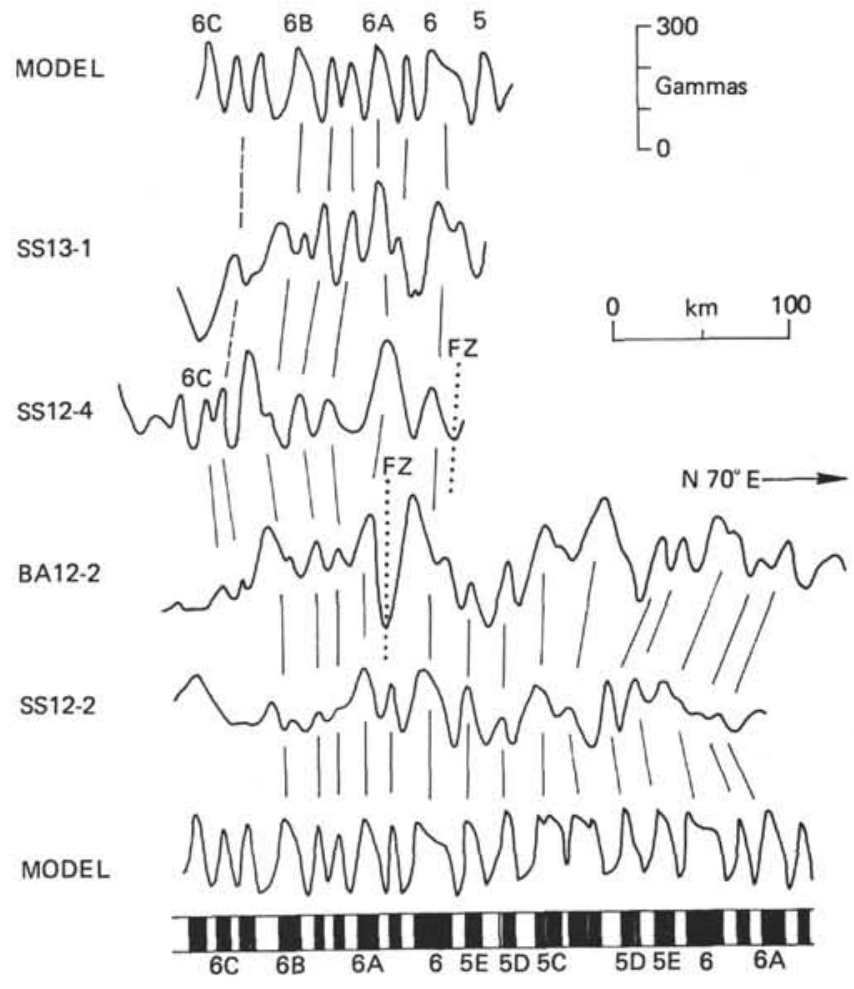

Figure 6. Selected magnetic-anomaly profiles (projected normal to the lineation direction in the basin) showing a two-limbed spreading sequence at the southern part of the Shikoku Basin. The correlations of the older anomalies in this basin, the $6 C-6 B$ sequence, are also shown. Tracks of these profiles are shown in Figure 4. 


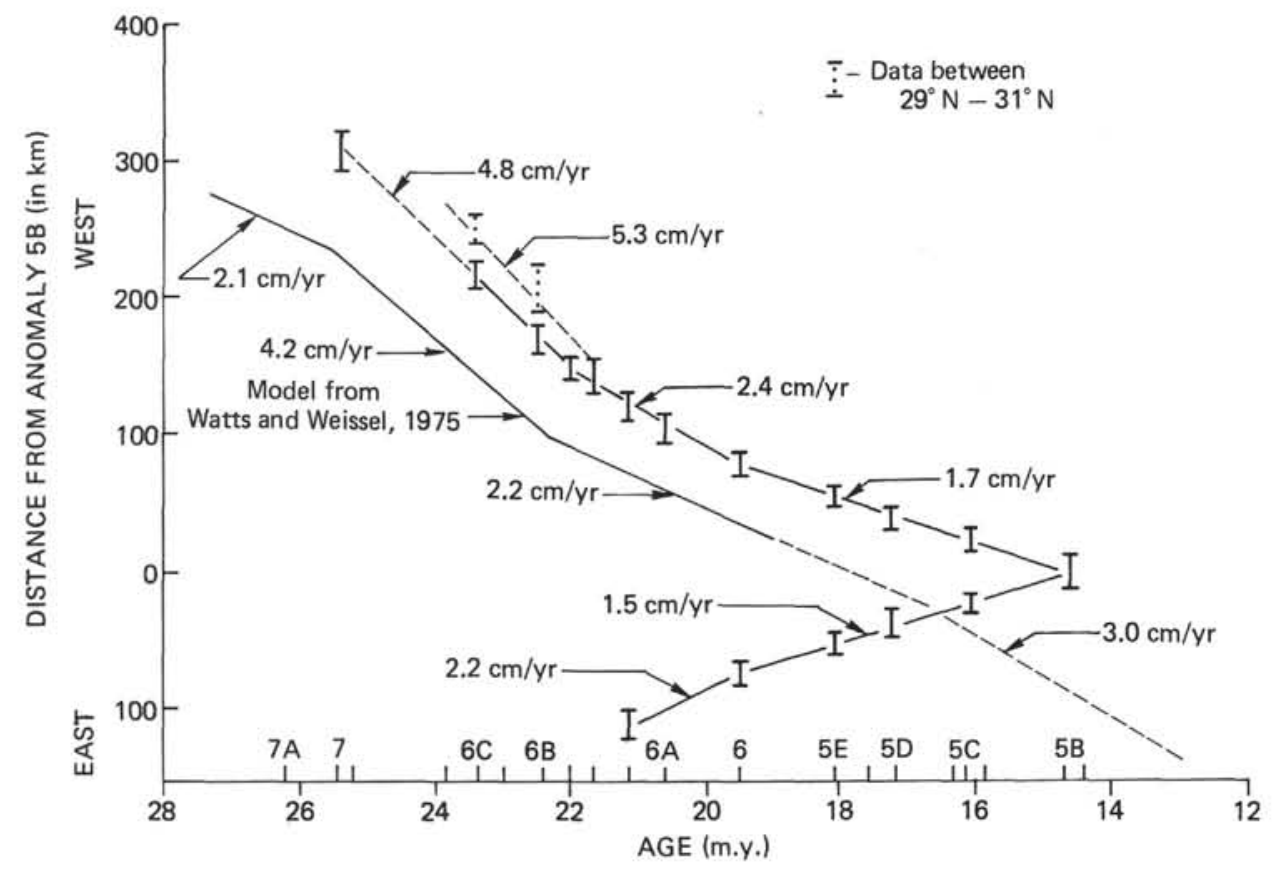

Figure 7. Distance-age plot showing spreading rates derived from interpretation of magnetic anomalies from the Shikoku Basin. The model of Watts and Weissel (1975) is also shown.

for the 200-km difference in the width of the basin. My correlation of magnetic anomalies in the southern part of the basin has indicated that anomaly $5 \mathrm{C}$ is the central anomaly (Figure 6), whereas about $100 \mathrm{~km}$ north anomaly $5 \mathrm{~B}$ is the central anomaly (Figure 2 ). This suggests that the Shikoku Basin first stopped spreading in the southern part and later in its northern part, resulting in the "fanning" of the basin.

DSDP Site 442 is on a magnetic anomaly generally accepted as anomaly $6(\sim 19.5$ m.y.; Watts and Weissel, 1975; Kobayashi and Nakata, 1978; this study). The inferred age of the basaltic basement is 18 to 21 m.y. (Klein, Kobayashi, et al., 1978; Scientific Staff, 1978), which agrees with the age of anomaly 6 . The middleMiocene basement age ( $\sim 15$ m.y.) inferred from DSDP drilling at Sites 443 and 444 does not support previously predicted ages (Table 1). According to my correlation (Figure 2), Site 443 is between anomalies 5D and 5C ( $\sim 16-17$ m.y.), and Site 444 is on anomaly 5D $(\sim 17$ m.y.). If a gap of 1 to $2 \mathrm{~m}$.y. between the age of the basement and that of the basal sediment is allowed, my correlation of the magnetic anomalies from the eastern part of the Shikoku Basin agrees very well with the DSDP results.

The oldest anomalies which I have identified with assurance in the western part of the Shikoku Basin are anomalies $6 \mathrm{~B}(\sim 22.5 \mathrm{~m}$.y.) to $6 \mathrm{C}(\sim 24 \mathrm{~m} . \mathrm{y}$.), while the oldest in the eastern part is anomaly $6 \mathrm{~A}(\sim 21 \mathrm{~m} . \mathrm{y}$. (Figure 1). Later tectonism associated with the Iwo Jima Ridge may have destroyed the eastern counterparts of anomalies $6 \mathrm{C}$ to $6 \mathrm{~B}$ and probably also disrupted the lineation pattern in the eastern part of the Shikoku Basin.

\section{ORIGIN OF THE SHIKOKU BASIN}

The magnetic lineations in the Shikoku Basin are subparallel to the Iwo Jima Ridge (the abandoned frontal arc) and to the northern segment of the Palau-Kyushu Ridge (the remnant arc) (Figure 1). This suggests rather strongly that the Shikoku Basin was formed by back-arc spreading in response to the westward subduction of the Pacific plate. The age of the basin inferred from magnetic lineations and DSDP drilling is Oligocene to Miocene (this study; Klein, Kobayashi, et al., 1978; Scientific Staff, 1978), while the oldest rocks of the Iwo Jima Ridge and the Palau-Kyushu Ridge are Eocene (Yoshiwara, 1902; Shiki et al., 1977; Scientific Staff, 1978). Both the crust and lithosphere of the Shikoku Basin are thinner than those of the oceanic area (Murauchi et al., 1968; Seekins and Teng, 1977). Therefore, I suggest that Shikoku Basin was created by back-arc spreading.

The Shikoku Basin probably started to open about 25 $\mathrm{Ma}-15 \mathrm{~m} . \mathrm{y}$. after the initiation of subduction $(40 \mathrm{Ma})$ inferred from the change in the Pacific-plate motion. This would suggest that the time needed for the presumed secondary convection current to heat up and weaken the crust, so that back-arc spreading could start, is less than that proposed by Toksöz and Bird (1977).

As to the possible cause of the disrupted lineations in the eastern part of the basin, the subduction of the "buoyant" Mid-Pacific Mountains at the Izu-Bonin Trench could obstruct the back-arc spreading in the Shikoku Basin (in a way similar to the suggestions of Vogt et al., 1976, and Kelleher and McCann, 1977). This probably would result initially in a shift of the pole of 
opening of the Shikoku Basin at $\sim 17$ to $18 \mathrm{Ma}-$ expressed as the change in lineation directions between anomalies 5E and 5D - and, later, cessation of spreading in the basin. The back-arc spreading about the new pole could produce fracture zones or activate previous zones of weakness in the eastern Shikoku Basin, thus producing the observed disrupted lineation pattern.

\section{ACKNOWLEDGMENTS}

I thank Wilbert Geddes for providing the MGS data. A. B. Watts and J. K. Weissel also made available to this study their magnetic anomaly data in the Shikoku Basin. I appreciate support and encouragement from Creighton A. Burk and George deVries Klein. Discussions with John W. Ladd, Wulf A. Gose, Hong-Bing Liaw, and $\mathrm{H}$. James Dorman were particularly helpful. The University of Texas Marine Science Institute provided financial support and computer facilities. Manuela E. Dill typed the manuscript.

\section{REFERENCES}

Ben-Avraham, Z., and Uyeda, S., 1973. The evolution of the China Basin and the Mesozoic paleogeography of Borneo. Earth Planet. Sci. Lett., 17, 365-376.

Chase, T. E., and Menard, H. W., 1969. Bathymetric Atlas of the Northwestern Pacific Ocean: Washington (U. S. Naval Oceanogr. Office).

Cooper, A. K., Marlow, M. S., and Scholl, D. W., 1976. Mesozoic magnetic lineations in the Bering Sea marginal basin. J. Geophys. Res., 81, 1916-1934.

Hasebe, K., Fujii, N., and Uyeda, S., 1970. Thermal processes under island arcs. Tectonophysics., 10, 335-355.

Heirtzler, J. R., Dickson, G. O., Herron, E. M., Pitman, W. C., and LePichon, X., 1968. Marine magnetic anomalies, geomagnetic anomalies, geomagnetic field reversals and motions of the ocean floor and continents. J. Geophys. Res., 73, 2119-2136.

Holmes, A., 1965. Principles of Physical Geology: London, (Thomas Nelson).

IAGA [Commission 2, Working Group 4], 1969. International geomagnetic reference field 1965.0. J. Geophys. Res., 74, 4407-4408.

Isezaki, N., and Uyeda, S., 1973. Geomagnetic anomaly of the Japan Sea. Mar. Geophys. Res., 2, 51-59.

Karig, D. E., 1970. Ridges and basins of the Tonga-Kermadec arc system. J. Geophys. Res., 75, 239-254.

1971. Origin and development of marginal basins in the western Pacific. J. Geophys. Res., 76, 2452-2561.

Karig, D. E., and Moore, G. F., 1975. Tectonic complexities in the Bonin island arc system. Tectonophysics, 27, 97-118.

Klein, G. deV., Kobayashi, K., et al., 1978. Off-ridge volcanism and sea-floor spreading in the Shikoku Basin. Nature, $273, .746-748$.

Kelleher, J., and McCann, W., 1977. Bathymetric highs and development of convergent plate boundaries. In Talwani, M., and Pitman, W. C. III (Eds.) Island Arcs, Deep-Sea Trenches, and Back-Arc Basins: Am. Geophys. Union Maurice Ewing Series 1, pp. 115-122.

Kobayashi, K., and Nakata, M., 1977. Local magnetic anomaly profile, Shikoku Basin, northwest Pacific Ocean. Contr. Geodynamics Project Japan, 77-2.
1978. Magnetic anomalies and tectonic evaluation of the Shikoku inter-arc basin, northwestern Pacific Margin. Internat. Geodynamics Conf., Tokyo (Abstract).

LaBrecque, J. L., Kent, D. V., and Cande, S. C., 1977. Revised magnetic polarity time scale for Late Cretaceous and Cenozoic time. Geology, 5, 330-335.

Moberly, R., 1972. Origin of lithosphere behind island arcs with reference to the western Pacific. In Shagam, A., et al., (Eds.), Studies in Earth and Space Science: Geol. Soc. Am. Mem. 132, pp. 35-55.

Morley, L. W., and Larochelle, A., 1964. Paleomagnetism as a means of dating geological events. Roy. Soc. Can. Spec. Publ. 8, 512-521.

Murauchi, S., Den, N., Asano, S., Hotta, H., Yoshii, T., Hagiwara, K., Ichikawa, K., Sato, T., Ludwig, W. J., Ewing, J. I., Edgar, N. T., and Houtz, R. E., 1968. Crustal structure of the Philippine Sea. J. Geophys. Res., 73, 3142-3171.

Murauchi, S., and Asanuma, T., 1978. Seafloor spreading in the Shikoku Basin, south of Japan. Internat. Geodynamics Conf., Tokyo. (Abstract)

Packham, G. H., and Falvey, D. A., 1971. An hypothesis for the formation of marginal seas in the western Pacific. Tectonophysics, 11, 79-109.

Scientific Staff, 1978. Philippine Sea drilled. Geotimes, 23, no. 5, 23-25.

Seekins, L. C., and Teng, T. L., 1977. Lateral variations in the structure of the Philippine Sea plate. J. Geophys. Res., 82, 317-324.

Shiki, T., Misawa, Y., Konda, I., and Nishimura, A., 1977. Geology and geohistory of the northwestern Philippine Sea, with special reference to the results of the recent Japanese research cruises. Mem. Fac. Sci. Kyoto Univ., Ser. Geol. Min., 44, 67-78.

Toksöz, M. N., and Bird, P., 1977. Formation and evolution of marginal basins and continental plateaus. In Talwani, M., and Pitman, W. C. III (Eds.), Island Arcs, Deep Sea Trenches, and Back-Arc Basins. Am. Geophys. Union Maurice Ewing Series 1, pp. 379-393.

Tomoda, Y., Kobayashi, K., Segawa, J., Nomura, M., Kimura, K., and Saki, T., 1975. Linear magnetic anomalies in the Shikoku Basin, northwestern Philippine Sea. J. Geomagnet. Geoelec., 27, 47-56.

Turcotte, D. L., and Oxburgh, E. R., 1969. A fluid theory for the deep structure of dip-slip fault zones. Phys. Earth Planet. Interiors, 1, 381-386.

Vine, F. J., and Matthews, D. H., 1963. Magnetic anomalies over ocean ridges. Nature, 199, 946-949.

Vogt, P. R., Lowrie, A., Bracey, D. R., and Hey, R. H., 1976. Subduction of aseismic oceanic ridges: effects on shape, seismicity and other characteristics of consuming plate boundaries. Geol. Soc. Am. Sp. Paper, 172.

Watts, A. B., and Weissel, J. K., 1975. Tectonic history of the Shikoku marginal basin. Earth Plant. Sci. Lett., 25, 239-250.

Watts, A. B., Weissel, J. K., and Davey, F. J., 1977. Tectonic evolution of the South Fiji marginal basin. In Talwani, M., and Pitman, W. C., III (Eds.), Island Arcs. Deep-Sea Trenches and Back-Arc Basins. Am. Geophys. Union Maurice Ewing Series 1, pp. 419-427.

Yoshiwara, S., 1902. Geological age of the Ogasawara Group (Bonin Islands) as indicated by the occurrence of Nummulites. Geol. Mag., 9, 296-303. 